\title{
Kecacingan pada kucing di Klinik Star Vet Bogor
}

\author{
Alif Nur Muhamad Muriana ${ }^{1, *}$, Yusuf Ridwan ${ }^{2}$, Risa Tiuria $^{2}$, Rizal Arifin Akbari $^{3}$ \\ ${ }^{1}$ Program Sarjana, Fakultas Kedokteran Hewan, Institut Pertanian Bogor, Bogor \\ ${ }^{2}$ Divisi Parasitologi dan Entomologi Kesehatan, Departemen Ilmu Penyakit Hewan dan Kesmavet, Fakultas Kedokteran \\ Hewan, Institut Pertanian Bogor, Bogor \\ ${ }^{3}$ Klinik Hewan Star Vet, Cimanggu Kota Bogor
}

\begin{abstract}
ABSTRAK: Helminthiasis adalah salah satu penyakit yang perlu diperhatikan pada kucing karena tidak menimbulkan gejala klinis yang serius, kecuali pada infeksi berat dan kronis. Penelitian ini bertujuan mempelajari kejadian kecacingan pada kucing di klinik hewan Star Vet Bogor. Data sekunder didapat dari rekam medis periode 2016-2018 dengan total kasus yang ditangani berjumlah 2 535. Total kasus yang diduga kecacingan pada kucing sebesar 49 kasus. Kasus kucing yang positif kecacingan sebesar 43 kasus dan negatif sebesar 6 kasus. Kucing dapat terinfeksi lebih dari satu jenis cacing parasit pada satu waktu yang sama. Jenis cacing parasit yang berhasil diidentifikasi adalah hookworm sebesar 14 dari 27 kasus, Toxocara sp sebesar 11 dari 27 kasus, dan Dipylidium sp sebesar 2 dari 27 kasus. Antelmintika yang banyak digunakan untuk mengobati kasus kecacingan pada kucing memiliki zat aktif praziquantel dan pirantel pamoat.
\end{abstract}

Kata kunci:

antelmintika, cacing, helminthiasis, kucing, klinik hewan

\section{- PENDAHULUAN}

Kecacingan atau helminthiasis adalah salah satu penyakit yang perlu diperhatikan pada kucing. Kecacingan sering diabaikan karena tidak menimbulkan gejala klinis yang serius, kecuali pada infeksi berat dan kronis (Soeharsono 2007). Prevalensi helminthiasis pada kucing di Surabaya sebesar 60,9\% (Kusnoto 2005), Denpasar sebesar 32,5\% (Nealma et al. 2013) dan Bogor sebesar 53,5\% (Murniati et al. 2016). Kota Bogor merupakan salah satu kota yang memiliki kelembaban cukup tinggi, sehingga dapat memicu kenaikan prevalensi infeksi cacing (Murniati et al. 2016). Rekam medis dapat digunakan sebagai sarana penelusuran kasus penyakit. Penelitian ini menggunakan data rekam medis di klinik hewan Star Vet, Kota Bogor.

\section{- BAHAN DAN METODE}

Pengambilan Data. Data yang digunakan berupa 2535 data rekam medis periode 2016-2018 pada klinik hewan Star Vet Kota Bogor. Data yang diambil adalah data rekam medis yang diduga terkena infeksi cacing dan dilakukan uji laboratorium. Data yang didapat kemudian disimpan dalam bentuk tabel yang memuat informasi berupa kode pasien, anamnese, signalement, dan treatment.

Analisis Data. Data yang diperoleh dari hasil pengamatan dimasukkan ke dalam program microsoft excel. Analisis data dilakukan secara deskriptif dari rekam medis.

\section{- HASIL DAN PEMBAHASAN}

Jenis Infeksi Cacing. Seluruh data rekam medis periode 2016-2018 yang berada di klinik hewan Star Vet Kota
Bogor berjumlah 2535 kasus. Total kasus yang diduga kecacingan pada kucing sebesar 49 kasus. Total keseluruhan kasus yang positif kecacingan sebesar 43 kasus dan negatif sebesar 6 kasus. Berdasarkan data rekam medis, gejala yang timbul dari kasus kecacingan adalah diare. Menurut Nelson \& Couto (2003), diare merupakan peningkatan frekuensi pengeluaran feses yang mengandung air melebihi normal. Diare terjadi bila terdapat gangguan transpor terhadap air dan elektrolit pada saluran cerna. Diare merupakan gejala klinis umum yang dapat terjadi pada beberapa penyakit. Menurut Rahmadani (2015) selain infeksi parasit saluran cerna diare dapat disebabkan oleh gangguan penyerapan makanan di usus, gangguan metabolik, dan infeksi virus.

Kejadian kecacingan di klinik hewan Star Vet Bogor dilaporkan mencapai 49 kasus. Seluruh kasus kucing yang diduga kecacingan terdapat 6 kasus yang tidak menunjukkan hasil terjadi infeksi cacing. Prevalensi kasus kecacingan di klinik hewan Star Vet Bogor periode 20162018 sebesar $1,7 \%$. Kucing dapat terinfeksi oleh lebih dari satu jenis parasit pada satu waktu yang sama. Infeksi ganda memiliki jumlah kejadian yang lebih sedikit daripada infeksi tunggal (Tabel 1). Kombinasi infeksi ganda yang terjadi adalah Toxocara sp dengan hookworm dan Toxocara sp dengan Dypilidium sp. Hasil rekam medis menunjukkan terdapat kasus yang tidak menjelaskan secara detil infeksi

Diterima: 16-09-2018 | Direvisi: 22-10-2018 | Disetujui: 25-10-2018 (C) 2018 CC-BY-SA. Ini adalah artikel Open Access yang didistribusikan berdasarkan ketentuan dari Creative Commons Attribution ShareAlike 4.0 International License (https://creativecommons.org/licenses/by-sa/4.0/). 
cacing yang terjadi. Pemeriksaan yang dilakukan tersebut hanya dilakukan sampai tingkat genus.

Tabel 1 Jenis infeksi cacing pada kucing di klinik hewan Star Vet Kota Bogor periode 2016-2018

\begin{tabular}{lccc}
\hline $\begin{array}{l}\text { Infeksi cacing } \\
\text { parasit }\end{array}$ & $\begin{array}{c}\text { Jumlah } \\
\text { sampel (N) }\end{array}$ & $\begin{array}{c}\text { Jumlah } \\
\text { positif } \\
\text { infeksi (n) }\end{array}$ & $\begin{array}{c}\text { Persentasi } \\
(\%)\end{array}$ \\
\hline $\begin{array}{l}\text { Infeksi tunggal } \\
\text { Infeksi ganda }\end{array}$ & 43 & 21 & 48,8 \\
$\quad 43$ & 6 & 18,6 \\
$\quad \begin{array}{l}\text { Toxocara } \text { sp dan } \\
\text { Tooxorm }\end{array}$ & 43 & 3 & 6,9 \\
$\begin{array}{l}\text { Toxpara sp dan } \\
\text { Dipyidium sp }\end{array}$ & 43 & 3 & 6,9 \\
$\begin{array}{l}\text { Jenis cacing tidak } \\
\text { diidentifikasi pada } \\
\text { rekam medis }\end{array}$ & 43 & 16 & 37,2 \\
\hline
\end{tabular}

Jenis cacing parasit yang teridentifikasi oleh uji natif dan uji pengapungan adalah hookworm sebanyak 14 dari 27 kasus, Toxocara sp sebanyak 11 dari 27 kasus, dan Dipylidium sp sebanyak 2 dari 27 kasus. Hal ini sesuai dengan Oktaviana et al. (2014) yang menyatakan bahwa, terdapat beberapa jenis parasit yang sering ditemukan pada saluran pencernaan kucing seperti Ancylostoma sp, Toxocara sp, dan Strongyloides sp.

Antelmintika. Pemberian antelmintika merupakan cara penanggulangan kasus kecacingan. Kombinasi obat yang paling banyak digunakan adalah kombinasi obat praziquantel dan pirantel pamoat (Tabel 2). Menurut Tjay dan Raharja (2015) pengobatan pada kasus Ancylostomiasis (hookworm) dapat diobati dengan pemberian bahan aktif pirantel pamoat. Kasus infeksi oleh cacing Toxocara sp pada kucing dapat diberi terapi berupa pirantel pamoat atau levamisole. Dipylidium sp termasuk ke dalam kelas cacing cestoda. Menurut Tjay dan Raharja (2015), terapi yang tepat pada infeksi cacing cestoda pada kucing yaitu menggunakan praziquantel karena bahan aktif tersebut memiliki aktivitas terhadap cacing cestoda.

Penegakan diagnosa adalah hal yang penting dalam penentuan terapi. Ketepatan identifikasi parasit sangat dibutuhkan guna memberikan terapi yang tepat. Pada data rekam medis klinik hewan Star Vet Bogor, terdapat beberapa kasus kecacingan pada kucing yang tidak diidentifikasi hingga ke genus cacing. Terapi yang digunakan pada kasus tersebut adalah pemberian kombinasi praziquantel dan pirantel pamoat. Kedua bahan aktif tersebut memiliki spektrum yang luas, namun praziquantel dan pirantel tidak memiliki aktivitas yang baik terhadap cacing hati (Tjay dan Raharja 2015). Pemberian kombinasi tersebut akan kurang efektif jika terjadi infeksi cacing hati. Kombinasi obat praziquantel, pirantel pamoat, dan fenbendazole adalah rekomendasi yang lebih baik dalam terapi pada kasus tersebut. Efektifitas praziquantel dan pirantel pamoat ditambah dengan fenbendazole yang merupakan derivat dari benzimidazole memiliki spektrum luas (Klausz et al. 2001). Pemilihan tersebut tepat sasaran karena dapat mengurangi kemungkinan kegagalan dalam terapi. Penegakan diagnosa infeksi parasit sebaiknya dilakukan hingga mencapai genus parasit untuk mengurangi kesalahan pemberian terapi.

Tabel 2 Obat yang digunakan di klinik hewan Star Vet Kota Bogor periode 2016-2018

\begin{tabular}{|c|c|c|c|c|c|}
\hline \multirow[b]{2}{*}{ Jenis cacing parasit } & \multirow[b]{2}{*}{$\mathrm{N}$} & \multicolumn{4}{|c|}{ Kombinasi obat } \\
\hline & & $\mathrm{A}$ & $\mathrm{B}$ & $\mathrm{C}$ & $\mathrm{D}$ \\
\hline Jenis cacing tidak & & & & & \\
\hline $\begin{array}{l}\text { diidentifikasi pada rekam } \\
\text { medis }\end{array}$ & 16 & 12 & 2 & 0 & 2 \\
\hline Hookworm sp & 14 & 12 & 0 & 1 & 1 \\
\hline Toxocara $\mathrm{sp}$ & 11 & 8 & 1 & 2 & 0 \\
\hline Dipylidium $\mathrm{sp}$ & 2 & 1 & 0 & 1 & 0 \\
\hline Total & 43 & 33 & 3 & 4 & 3 \\
\hline
\end{tabular}

Keterangan : A: Praziquantel dan Pirantel Pamoat, B: Mebendazole dan Levamisole, C: Pirantel Pamoat, D: Praziquantel,Pirantel Pamoat dan Fenbendazole

\section{SIMPULAN}

Prevalensi kasus kecacingan di klinik hewan Star Vet Bogor periode 2016-2018 sebesar 1,7\%. Jenis cacing parasit yang berhasil diidentifikasi pada kucing di klinik hewan Star Vet Bogor adalah hookworm sebanyak 14 dari 27 kasus, Toxocara sp sebanyak 11 dari 27 kasus, dan Dipylidium sp sebanyak 2 dari 27 kasus. Antelmintika yang paling banyak digunakan adalah praziquantel dan pirantel pamoat.

\section{- INFORMASI PENULIS}

Penulis untuk Korespondensi

*IAS: ryanrocket16@gmail.com

Fakultas Kedokteran Hewan, Institut Pertanian Bogor, Bogor Jl. Agatis Kampus IPB Dramaga Bogor 16680

\section{- PUSTAKA ACUAN}

Klausz G, Keller W, Sára Z, Székely-Körmöczy P, Laczay P, Ary K, Sótonyi P, Róna K. 2015. Simultaneous determination of praziquantel, pyrantel embonate, febantel and its active metabolites, oxfendazole and fenbendazole, in dog plasma by liquid chromatography/mass spectrometry. Biomedical Chromatography, 29(12): 1859-1865.

Kusnoto. 2005. Prevalensi toxocariasis pada kucing liar di Surabaya melalui bedah saluran pencernaan. Media Kedokteran Hewan. 21(1): 7-11.

Murniati, Sudarnika E, Ridwan Y. 2016. Prevalensi dan faktor risiko infeksi Toxocara cati pada kucing peliharaan di Bogor. Jurnal Kedokteran Hewan. 10(2): 139-142.

Nealma S, Dwinata IM, Oka IBM. 2013. Prevalensi infeksi cacing Toxocara cati pada kucing lokal di wilayah Denpasar. Jurnal Medical Veterinary Indonesia. 2(4): 428- 436.

Nelson RW, Couto CG. 2003. Small Animal Internal Medicine. 3rd edition. Missouri (US): Mosby Inc.

Oktaviana PA, Dwinata P, Oka IBM. 2014. Prevalensi infeksi cacing Ancylostoma spp pada kucing lokal (Felis catus) di kota Denpasar. Buletin Veteriner Udayana. 6(2): 161-167

Rahmadani S. 2015. Evaluasi helmintiasis pada anjing penderita diare di klinik hewan Makassar. [SKRIPSI]. Makassar (ID): Universitas Hasanudin Makassar.

Soeharsono. 2007. Penyakit Zoonotic pada Anjing dan Kucing. Yogyakarta (ID): Kanisius.

Tjay HT, Rahardja K. 2015. Obat-Obat Penting Khasiat, Penggunaan dan Efek-Efek Sampingnya, Edisi Ketujuh. Jakarta (ID): PT. Elex Media Komputindo.

http://journal.ipb.ac.id/index.php/arshivetlett 